\title{
THE EMERGENCE OF LOCAL COFFEE SHOPS IN INDONESIA AS A COUNTER TO AMERICAN CULTURE HEGEMONY
}

\author{
Siti Nurhasanah \\ University of Indonesia \\ e-mail: husna.rifa04@gmail.com \\ Chika Dewi \\ University of Indonesia \\ e-mail: chikchikadewi@gmail.com
}

\begin{abstract}
After winning World War II, the United States (US) tried to spread its hegemony in almost all aspects, including culture. Starbucks has become the biggest MNC belong to the US that spreads western culture in Indonesia. Starbucks, with its 326 outlets in Indonesia, has brought its new value to Indonesian society. In this paper, the writer would like to analyze the response of Indonesians in dealing with the cultural hegemony that Starbucks brings as the representation of the American culture. This paper uses library research as the data collection method and qualitative method in analyzing the data. The writer analyzes this case by applying the circuit of culture theory, which consists of 5 aspects: production, consumption, regulation, representation, and identity. The writer will focus on how local coffee shops adopt the management and production process from Starbucks applied in their coffee shops. The creativity of Indonesians has made new cultures are quickly adopted. The advent of Starbucks in Indonesia had stimulated the establishment of local coffee shops that are not less competitive with Starbucks as the giant coffee shop corporation. The local coffee shops can give a unique experience in enjoying a coffee just like Starbucks with its "Starbucks Experience". The local coffee shops also can provide not only coffee, but also other products that might take the interest of customers. The local coffee shops are able to imitate, and modify Starbucks concept in local versions.
\end{abstract}

Keywords: Starbucks; circuit of culture; production; local coffee; coffee culture

\author{
Article information \\ Received: 9 January, 2019 \\ Revised:23 January, 2019 \\ Accepted: 6 February, 2019
}

DOI $\quad:$ https://doi.org/10.22146/rubikon.v6i1.61485

Available at https://jurnal.ugm.ac.id/rubikon/article/view/61485

This work is licensed under a Creative Commons Attribution-ShareAlike 4.0 International License 


\section{INTRODUCTION}

In the modern era, coffee culture has become the way of life among the community, including young people, both in developed and developing countries. In Indonesia, coffee culture has become a trend among young people, where the culture of coffee is used as an instrument for young Indonesian just to meet friends, family, or even do homework and assignment. In addition, the development of coffee culture in Indonesia had become one of the driving factors for many developed countries such as the US, to establish coffee shops in developing countries such as Indonesia.Coffee shops owned by developed countries such as the US usually serve coffee, tea, or other types drink, and also provide snacks and foods such as French fries, cakes, pastries, bread, donuts and pasta.

Not only that, the US coffee shop also provides adequate facilities for coffee connoisseurs, cozy room with air conditioner and most importantly can access free WiFi. The existence of free WiFi that makes young people willing to linger at the coffee shop just to get free WiFi (Hashim, Mamat, \& Halim, 2017). For price issues, of course coffee shops from the US put up prices that are high enough to just drink coffee. However, some young people are willing to pay dearly for higher quality (Hashim, Mamat, \& Halim, 2017). In other words, with many facilities offered by the US coffee shops, it certainly becomes an attraction for consumers. Especially among young people to have a coffee in the US coffee shops. It indirectly thrives the culture hegemony of US through coffee culture.
Based on this, it can be seen that the US is indeed a country that has power to build an empire under its power through aspects that can control the world, as well as the coffee culture. The culture of coffee looks trivial but has a big impact. In this case, the US spreads and implements its influence through coffee culture to the world, especially Indonesian, despite the current increasingly multipolar power in international world. One of forms of expansion through the coffee culture from the US is the emergence of international coffee shop owned by the US called Starbucks. Starbucks is used as a business opportunity and an instrument to spread the influence of US culture hegemony. Starbucks is international coffee corporation that focuses on products and the development of a variety of flavors.

In Indonesia, Starbucks was first opened in 2002 at Plaza Indonesia, Jakarta. As January 2018, Starbucks outlets in Indonesia has grown to 326 outlets in 22 cities (Starbucks Indonesia, 2018). With so many Starbucks outlets in Indonesia, it makes the US easier to spread and instill coffee culture to make it popular in Indonesia. Currently, drinking coffee at Starbucks is considered as a lifestyle for people in urban areas, such as Jakarta. Indeed, Indonesian are used to drink coffee. But the style in enjoying coffee has a lot changed. Previously, not all ages like coffee, the typical coffee lovers are men ages 20-60. That is because the coffee is pure, only added with sugar so that men drink coffee to get rid of drowsiness. However, Starbucks has changed that mindset. After the advent of Starbuck, coffee can be enjoyed by everyone both men and women from all ages, even kids. This is because the variants of coffee are very various, not pure as before. It is mixed with other substances such as 
milk, fruit, chocolate so that the image of coffee has expanded the customers of coffee and can be enjoyed anytime.

Indonesian who visit Starbucks are not only for coffee, but they want recognition for being a cool or an up-to-date person. This is a real proof that coffee has become a lifestyle. According to du Gay in the circuit of culture theory, the cultural production does not only refer to products that are traditionally related to literature, film, and music but also anything that is intentionally made with a specific meaning or purpose when circulated. These products can be superficial, as coffee (du Gay, Hall, Janes, Mackay, \& Negus, 1997). Coffee is software in influencing young people tocreate a new lifestyle, while Starbucks is the hardware in delivering that mission.

As time goes by, the presence of Starbucks was precisely the driving factor for the growth of the local coffee shops industry in Indonesia. Local coffee shops are increasingly established due to an increase in coffee consumption. In fact, the local coffee shops are in a high demand. Many local companies or individuals establish local coffee shops with various uniqueness and a large scale of promotion. In addition, more shops provide modern coffee makers that can make the best taste of the coffee (Farokhah \& Wardhana, 2017).

With the rapid growth of local coffee shops in Indonesia it also paves the way for the advancement of Indonesian local coffee productions. Indonesian coffee which is already well known has a distinctive taste, such as Gayo coffee, Toraja coffee, Flores coffee, Luwak coffee and others. In other words, the rapid growth of local coffee shops in Indonesia also contributes to develop the industry in Indonesia and that means that the presence of multinational coffee shops from the US does not always become a boomerang for Indonesia. On the contrary, the presence of Starbucks in Indonesia has become the driving factor for the development of local coffee shops. The rapid development of the local coffee shops become the main instrument to counter the culture hegemony from the US. This phenomenon also indicates Indonesian subtle resistance to the culture hegemony that the United States is trying to build through the coffee culture in Indonesia. Based on the information above, this research is conducted in order to analyze how Indonesians response to the American culture hegemony brought by Starbucks. Through this research it can be understood how the presence of local coffee shops in Indonesia can also be an instrument to counter the US culture hegemony. The results of this research are expected to provide information and understanding about the impact of the United States culture hegemony through a coffee culture that does not always have a negative impact.

In order to understand the phenomenon on the emergence of local coffee shops after the advent of Starbucks in Indonesia, the writer has to use theory or concept which is relevant to this issue. In this paper, the writer would like to use Circuit of Culture theory. Circuit of culture is a series of five cultural processes used to interpret a text or cultural artifact (du Gay, Hall, Janes, Mackay, \& Negus, 1997). If a part of the process is felt to be sufficient to reveal the meaning of a text or cultural artifact, then it does not need all the processes applied. This theory was made by Paul du Gay and Stuart Hall in 1997 to observe Walkman. There are five aspects 
in the Circuit of Culture, but the most relevant one with this paper is production aspect. Hall in his book has stated that the process of production focus on entering into business and economic world.

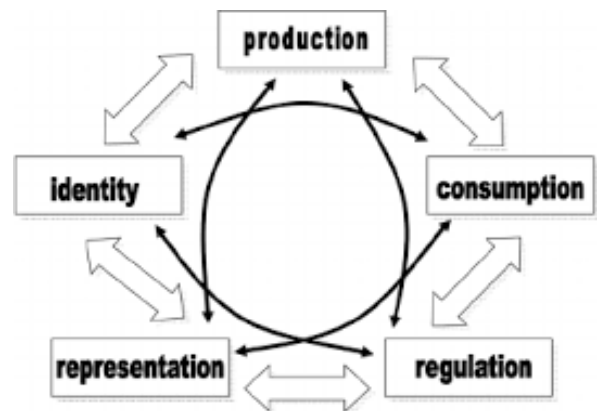

Figure 1. Circuit of Culture Model (Hall, 1997)

Du Gay also stated in his book that the "production of culture" does not only refer to the products that traditionally related to literature, film, and music, but also any goods that intentionally made with particular meanings and associations when they are produced and circulated. The product can be banal, such as coffee (du Gay, Hall, Janes, Mackay, \& Negus, 1997). In their research, du Gay classifies three kinds of cultural products: the Walkman, cassettes, and music (du Gay, Hall, Janes, Mackay, \& Negus, 1997). The Walkman is categorized as "cultural hardware" while the music is "cultural software". It is the similar case with the discussion in this paper, in which coffee shops as "cultural hardware" and coffee as "cultural software".

Related to the production of culture, it can be explained that Starbucks as the trendsetter in making style of enjoying coffee. In Indonesia coffee used to be seen as commodity for export or edible substance that contains high caffeine, well-known by its effectiveness in relieving drowsiness. Coffee was also only enjoyed by oldies or men who work in blue-collar sectors such as truck driver and construction workers. Coffee was also typically consumed in the morning. But after the advent of Starbucks, coffee is promoted to be consumed by people in all age range started from kids to oldies. This is because the coffee variants offered are various and have been mixed with several substances like cream, fruit, and milk. This invention has expanded the consumer of coffee.

In the following discussion, it will be revealed the production aspects that have shifted the "coffee culture" in Indonesia starting from the process of coffee making using particular tools and the setting of very convenient place that has pushed coffee to be more as lifestyle. Therefore, it is very relevant to use the production aspect of Circuit of Culture since the production consist of making the thing, inventing it, fabricating it, reproducing it, marketing it, distributing it, and paying for all the workers or labors.

\section{DISCUSSION}

Coffee culture is defined as the shifting of Indonesian in enjoying coffee from habit to become lifestyle. Café culture is part of shifting culture that previously Indonesian have coffee in Warung and home but now mostly have coffee in café (coffee shops). The culture of coffee is a transcultural meeting because of the culture that spreads from one region to another (Farokhah \& Wardhana, 2017). In this case, the culture of coffee brought by foreigners meets local cultures. Similar to the culture of coffee at Starbucks, which is brought and distributed by the US, it meets the culture in Indonesia that really likes to consume coffee. The character of Indonesian people also who tend to like 
gathering or just meeting old friends. The combination of cultures in Indonesia who like to consume coffee and like to gather with friends makes the culture of coffee at Starbucks grows and even becomes a lifestyle for the Indonesian.

However, the cultural development of coffee at Starbucks does not always have a negative impact on Indonesia. The coffee culture in Starbucks slowly encourages the interest of the coffee industry activists in Indonesia to innovate more. Seen today, more and more local coffee shops are emerging in various cities in Indonesia. Local coffee shops that develop in Indonesia have many variations, including coffee shops that are made for the purpose of drinking coffee and coffee shops are made not only for the purpose of drinking coffee, but also for the purpose of supporting lifestyle. The coffee shop has innovations starting from the type of coffee served, the atmosphere of the place, internet facilities and adequate parking. With the many innovations issued by local coffee shops in Indonesia, the prices offered are not expensive. Conversely, the price of coffee in local coffee shops in Indonesia is quite cheap, especially coupled with adequate facilities like the multinational coffee shop of the US, Starbucks. This is because some people, especially young people in Indonesia, have made coffee a part of life. In other words, local coffee shops in Indonesia are intended by various groups; upper, middle and lower.

There are three factors that influence Indonesia toaccept the coffee and café culture. First, basically, Indonesian are fond of coffee, that has become an effective drink to stay awake more with the high caffeine substance inside it. This can be defined as local culture meets foreign culture that resulted in the mixed culture.Second, the nature of Indonesian who like to gather with friends and family in the spare time. The sense of family in Indonesia is very high. The coffee shops are very comfortable to become venue for any events, therefore Indonesian choose coffee shops to gather.The last but not least, this phenomenon also can be seen from globalization perspective, the transition from traditional into modern society. Internet era also drives people to look for place which provided Wireless Fidelity (WiFi) to do the task or just connect with people in social media.

There are several indicators adopted by local coffee shops from Starbucks:

\section{Cozy place}

Warung Kopi in Indonesia is used to have simple place, only a room filled with men drinking coffee. But after the advent of Starbucks, the Warung Kopi are replaced by coffee shops with cozy room that provides enough space for a lot of people. The table are arranged beautifully and artsy.Students also can stay there longer because it provides electric plug for ones who want to keep the battery of their laptop and smartphone full.

\section{Facility}

Warung Kopi does not have any facility. But coffee shops have sufficient budget to make the customer want to stay longer. The main facilities are $\mathrm{WiFi}$ and air conditioner. The air conditioner keeps the room cool and very comfortable. The WiFi is really wanted by people who do not have internet connection in their house. 


\section{Management}

Local coffee shops adopt the system of Starbucks both inside the shop and the recruitment process of the labor. The labor is trained well so that instead of serving coffee, the barista is also friendly to the customer. The customer comes to the counter for ordering, the name is written, when coffee is ready, the barista will call the customer's name.The system is also similar to Starbucks in which the coffee can be ordered for either dine in or take away.

\section{Cooperation}

In attempt to make the shop being visited by more people, the shop usually makes cooperation with start-up delivery companies such as Gojek and Grab that provide take away system for the customer.

\section{Promotion}

Local coffee shops just like Starbuck use social media and website to promote their discount and new menu or variant. Indeed, social media plays a huge role in making people stay updated. Almost everyone in Indonesia use smartphone.

\section{Smoking area}

To make the customer more convenience, local coffee shops that have a large space create separate room for smoker and nonsmoker. It contains value of high tolerance toward customer who do not smoke.

\section{Parking Area}

The coffee shops owners realize that mostly Indonesian bring their own vehicles when visiting the place, therefore, the place should provide sufficient parking area to the convenience of the customer. The parking area is also kept by parking man who is ready to assist.

\section{Coffee variants}

Types of coffee variants inspired by Starbucks:

\section{a. Espresso}

Espresso is produced by extraction on coffee beans that have been through the grinding process. It needs an espresso machine to mix the coffee. This coffee is served fast. Making this espresso-style coffee began to be known in Italy.

\section{b. Latte}

Latte is coffee that combines espresso with milk. Most baristas say that the ideal ratio between coffee and milk is 3:1. The amount of coffee used is more than milk. Latte only has a small amount of thin foam on the surface of the coffee.

\section{c. Cappuccino}

This is the reverse of latte. The comparison between coffee and milk in a cappuccino is $1: 3$. This type of coffee blend is identic with the appearance a lot of foam on the surface and the taste is smooth and sweet. Cappuccino is mostly favored by coffee lovers who want to enjoy a light coffee because more milk in it.

\section{d. Frappe}

Unlike most other coffee, frappe is made using cold water to make an ice coffee. Frappe is made from instant coffee, water, sugar, and ice cubes. 


\section{e. Mochaccino}

The word mocha comes from an original coffee from Yemen called Mocha. Mochaccino comes from a mixture of espresso with chocolate and milk. The target of this coffee is chocolate lovers.

According to this, then with the presence of Starbucks in Indonesia, the local coffee industry in Indonesia also experienced improvisation because it made Starbucks the benchmark. The following are indicators that make local coffee in Indonesia undergo improvisation:

1. Larger space (not in mall, airport, or hotel)

The space of local coffee shops is generally larger than Starbucks. Some coffee shops are not located not in the downtown, it is located in the uptown. But the customers are willing to visit those places due to the ambience and the uniqueness of the concept. Some shops have garden concept in which customers enjoy coffee in an open space. Therefore, the large space is an advantage for the shops to develop the café concept better than Starbucks. Therefore, the customers are able to enjoy more than cozy place, but also peculiar thematic place.

\section{Unique concept}

While Starbuck provides comfortable place to sit, local coffee shops facilitate people for hangout. The unique concept consists of various ideas such as making the room exactly like in the office, provide bookshelf with various books inside, educating people by inviting them to the tea plantation, provide coffee lab to facilitate customers on how to make the coffee by themselves, and others. Indeed, Indonesian are very creative. They can create an artsy yet educative places. Some places are considered having sociopreneur concept that dedicated to the society. Moreover, the driven factor for customers to visit the places is photography and blogging for interesting contents in both social media and websites.

\section{Lavatory}

Not all Starbucks provide lavatory for the customer, only ones in the center of cities. But the local coffee shops are able to provide comfortable lavatory so that the customers are willing to stay a whole day there.

\section{Hospitality}

Starbucks have barista to only serve the coffee, but some local coffee shops are willing to teach the customers how to make coffee they want. It has the transparency on what the barista put inside the coffee to make it good. It also spread the ability of barista to the customer so that the customers might be interested to open their own coffee shops someday.

\section{Price}

Starbucks which located in airport, mall, and hotel sure they spend a lot of money for paying the taxes. While local coffee shops they are located not in public places so that they can sell coffee with a reasonable price. Starbucks is very expensive so that some people come there for pride, not for coffee. 
Table 1. The Comparison of Price for One Variant in Starbucks and Some Local Coffee Shops

\begin{tabular}{|c|c|}
\hline $\begin{array}{c}\text { Name of Coffee } \\
\text { Shop }\end{array}$ & $\begin{array}{c}\text { Price of } \\
\text { Cappuccino }\end{array}$ \\
\hline Starbucks & Rp. 46,000 \\
\hline RuangSeduh & Rp. 35,000 \\
\hline Armor Kopi & Rp. 25,000 \\
\hline $\begin{array}{c}\text { One Eighty } \\
\text { Coffee }\end{array}$ & Rp. 24,000 \\
\hline 7 Speed Coffee & Rp. 30,000 \\
\hline
\end{tabular}

(Sources: accessed through official websites, https://www.starbucks.com/,https://manual.co.id/directory/ruangseduh/, https://kumparan.com/@kumparanfood/5-kedai-kopi-unik-yang-wajib-kamu-kunjungi-ketika-berlibur-kebandung, https://manual.co.id/directory/7-speed-coffee/)

\section{Live music}

In addition to coffee, Indonesian also loves music. Local coffee shops have a special stage for the musician so that the customer can enjoy the music. They love to invite famous artists to take interest of the customers.

\section{Game tools}

To make the shops feels homey, they provide game tools such as bridge card, uno card, scrabble, and others. It takes the interest of young people who want to do activities with their friends or colleagues.

By looking at the development of local coffee in Indonesia, Indonesian coffee shops indirectly transformed from traditional to modern coffee shops. When it comes to coffee culture, Indonesian used to enjoy coffee in Warkop (Warung Kopi), but globalization as the driven factor spreading different way in enjoying coffee. Some aspects that shift the coffee culture in Indonesia can be explained in the following table:

Table 2. The Differences among Warkop (Warung Kopi), Coffee Shops, and Premium Coffee Shops in Indonesia

\begin{tabular}{|l|l|l|l|}
\hline Differences & Warung Kopi & \multicolumn{1}{|c|}{ Local Coffee Shops } & Premium Coffee Shops \\
\hline Glass & Porcelain glass & Porcelain glass, cup & Plastic glass, paper glass \\
\hline Facility & - & $\begin{array}{l}\text { WiFi, Air Conditioner, } \\
\text { plug, live music, game } \\
\text { tool, lavatory, smoking } \\
\text { area }\end{array}$ & $\begin{array}{l}\text { WiFi, Air Conditioner, } \\
\text { plug, smoking area }\end{array}$ \\
\hline $\begin{array}{l}\text { Coffee } \\
\text { making } \\
\text { method }\end{array}$ & $\begin{array}{l}\text { Normal brew } \\
\text { (stirring using } \\
\text { a spoon) }\end{array}$ & $\begin{array}{l}\text { Espresso machine, French } \\
\text { Press, Vietnam Drip, } \\
\text { Percolator }\end{array}$ & $\begin{array}{l}\text { Espresso machine, Pour } \\
\text { Over }\end{array}$ \\
\hline Topping & - & $\begin{array}{l}\text { Whipped cream, foam, } \\
\text { sugar, milk, syrup, } \\
\text { chocolate }\end{array}$ & $\begin{array}{l}\text { Whipped cream, sugar, } \\
\text { cream, syrup }\end{array}$ \\
\hline
\end{tabular}

Source: Meliala, Raden Roro Atiah Sekararum Dewanti. 2017. Tingkat Konsumsi Kopi Berdasarkan Pendapat, Usia, dan Harga di Kota Depok. Skripsi Universitas Islam Negeri Syarif Hidayatullah. 
The table above shows the transformation of coffee shops in Indonesia from traditional into modern one. Local coffee shops indeed adopt many aspects from Starbucks, but it turns out that local coffee shops can better improvise with the concepts they make because local coffee shops have a venue that was deliberately made for a café. From the table in terms of facilities, local coffee shops provide more facilities than the premium coffee shops because their venues are spacious, not limited. They are even able to provide lavatory, game tools that are very fun for groups to do when they are together. They provide live music with popular song they present.

The point is that the local coffee shops have more freedom to create a café according to the concept they really want. Because they are not franchise and they do not have the obligation to report to the center corporation, not affiliated with any multinational corporation. Based on the table, there are various types of coffee shops that are developing with all the facilities offered by each coffee shops. In addition, the table also shows that now Indonesian people tend to prefer coffee shops that are not premium types because the coffee shops provide a unique and comfortable atmosphere. Indeed, Starbucks is a premium type of coffee shop, but the atmosphere at Starbucks is somewhat monotonous because Starbucks is more in public places. In other words, local coffee shops in Indonesia are developing from the Starbucks concept and that means local coffee shops in Indonesia can fight the culture hegemony that has been spread by the United States. In addition, in today's digital era, Indonesian local coffee shops can easily carry out large-scale promotions on social media to introduce their coffee shops that are not inferior to Starbucks.

According to du Gay in the Cultural Circuit theory, coffee culture is a cultural product of the type of cultural software. The cultural phenomenon of coffee at Starbucks is not a serious threat to Indonesia because the phenomenon is only as a cultural shift towards a positive direction. Conversely, the coffee culture can be a software for Indonesia because it can bring up local coffee shops in Indonesia which are far better innovations. If the US produces Starbucks coffee shops to disseminate culture hegemony to Indonesia, then Indonesia can also produce local coffee shops to maintain the Indonesian coffee culture and create a great coffee industry. The more local coffee shops in Indonesia, the more local coffee production will increase and this will have an impact on the prosperity of coffee farmers. Those are 4 most favorable coffee shops in Indonesia with unique concept:

\section{Ruang Seduh}

RuangSeduh means Brewing Room. RuangSeduh is located in Jakarta and Yogyakarta. Ruang Seduh has a very unique concept in which the customers can make their own coffee. The following is written in Ruang Seduh website:

Think of Ruang Seduh like a guide for dummies on how to make your own cup of coffee. In this café, coffee enthusiasts will be presented with a non-intimidating guide by baristas without feeling like an actual dummy (Manual, 2015).

It looks like a lab with an interior that is stripped of colors. When the other cafes served the ready one, Ruang Seduh teaches the customer how to make it and what goes into it. Other cafes do not involve customer, 
the customer just goes to the counter to order then sit pretty. This cafe provides different yet unique way so that the customer can have experience in making a tasteful cup of coffee. Eventhough there is no exact science in preparing portions of cup of coffee, but everyone can make it with the help of the baristas.

\section{Armor Kopi}

This Coffee Shop has a very unique concept. This is located in the Great Forest Park Djuanda Dago, Bandung (Kumparan, 2017). The specialty of this Coffee Shop is the hot coffee because the weather there is cold. Therefore, coffee lovers can enjoy hot coffee in a cold condition. The view of this Coffee Shop also become the main interest for the customer because the café is located in the middle of the forest. This Coffee Shop is truly using "back to nature" concept.

\section{One Eighty Coffee}

This Coffee Shop is located in Geneca Street No.3, Bandung (Kumparan, 2017). This Coffee Shop is the one which provide the way to enjoy coffee in "relaxation" concept. What is unique about this place, every visitor is required to take off his feet to be able to soak his feet in the pool. The customers will have the real relaxation with this way of enjoying coffee. After finishing the coffee, the customers will feel fresh and ready to go back to work with a new spirit.

\section{7 Speed Coffee}

This Coffee Shop is located in North Kemang Street No.1, Jakarta (Manual, 2015). The name "7 Speed Coffee" is dedicated for local cycling and skating communities. The commitment is manifested in the decorations of the place which is full of skateboard and some bicycles. Skateboard desks are transformed into menus and the door handles are in form of bicycle bars. A BMX bike sits neatly at the back of the room serving as a backdrop to the gently-illuminated space (Manual, 2015). In this place, costumers can enjoy their coffee with a fresh air and possibly the occasional skateboard stunts from a group of skaters which become the special attraction only in this coffee shop.

By looking at the four examples of local coffee shops, it can be seen that the presence of Starbucks in Indonesia has opened up great opportunities for the coffee shop industry in Indonesia. The coffee shop is not only as a place to drink coffee, but also as a coffee drinking experience associated with social life (Yuliandri, 2015). In other words, the culture of drinking coffee has become part of the lifestyle and if someone has not visited the local coffee shop that provides sufficient facilities, then she or he will look less in association, especially for young people.

\section{CONCLUSION}

Based on the explanation above, it can be concluded that the response of Indonesian in dealing with the US culture hegemony is a resistance through actions. The action conducted by Indonesian is establishing their own coffee shops that are similar to Starbucks and even with a better concept. Indonesian adopts the management and system of Starbucks to be implemented in their coffee shops and can make several new innovations. It can be proven that the production of a multinational coffee shop like Starbucks does not always have a negative impact on Indonesia. On the contrary, the presence of Starbucks makes a cultural shift 
in coffee in Indonesia where previously only coffee was only consumed in the morning or evening and was only enjoyed by parents or people working in the field. However, slowly the culture of drinking coffee is identified with a coffee shop that has a comfortable place and contains coffee flavors, as well as providing a lifestyle for the people of Indonesia. With the coffee culture shift, it will also develop the local coffee shops industry which has innovated more than what Starbucks does. With the development of the local coffee shop industry, it also promotes coffee farmers and promotes Indonesian coffee products. In other words, aspects of cultural production mentioned by du Gay that have shifted the coffee culture in Indonesia, starting from the process of making coffee that uses sophisticated tools and a comfortable place which is the cultural driving factor of coffee used as a lifestyle.

\section{REFERENCES}

du Gay, P., Hall, S., Janes, L., Mackay, H., \& Negus, K. (1997). Doing Cultural Studies: The Story of the Sony Walkman. London: Open University/Sage.

Farokhah, F. A., \& Wardhana, A. S. (2017). Cafe versus Earkop (Warung Kopi): The Hegemony of Coffee Culture as TransCultural Encounters in Dewi Lestari's Filosofi Kopi. Literary Studies Conference 2017.

Hall, S. (1997). Representation: Cultural representation and signifying practices. London: SAGE Publication Ltd.

Hashim, N. H., Mamat, N. A., \& Halim, N. A. (2017). Coffee Culture Among Generation Y. Pertanika J. Soc. Sci \& Hum. 25.
Kumparan. (2017). 5 Kedai Kopi Unik yang Wajib Kamu Kunjungi Ketika Berlibur ke Bandung. Retrieved from https://kumparan.com/@kumparanfood/5 -kedai-kopi-unik-yang-wajib-kamukunjungi-ketika-berlibur-ke-bandung

Manual. (2015). 7 Speed Coffee. Retrieved from https://manual.co.id/directory/7speed-coffee/

Manual. (2015). Ruang Seduh. Retrieved from https://manual.co.id/directory/ruangseduh/

Meliala, R. R. (2017). Tingkat Konsumsi Kopi Berdasarkan Pendapatan, Usia, dan Harga di Kota Depok. Jakarta: Universitas Islam Negeri Syarif Hidayatullah Jakarta.

Starbucks Indonesia. (2018). Starbucks in Indonesia. Retrieved from http://www.starbucks.co.id/about-us/ourheritage/starbucks-in-indonesia

Yuliandri, M. T. (2015, August 6). Sejarah "First, Second and Third Wave Coffee". Otten Magazine. Retrieved from https://majalah.ottencoffee.co.id/sejarahfirst-second-and-third-wave-coffee/ 